\title{
Models of national referenda in Hungary - an overview starting from the change of political regime to the present day ${ }^{1}$
}

\author{
Csaba ERDŐS JD, PhD.
}

\begin{abstract}
The aim of this paper is to identify the trends and direction of Hungarian referenda-related legislation and their interpretation. The paper tries to determine the beneficiaries of the different models - for example the political elite (governmental or opposition parties), emerging political groups, or voters as non-professional (occasional) partakers of politics. The paper relies on the methodology of the science of constitutional law and it applies temporal comparison: it gives an overview of the changes in the regulation of national referenda in Hungary since the change of political regime. During three decades of the Third Hungarian Republic, the national referendum's constitutional role and model changed several times owing to the amendment of the relevant legislation and the changes in the Constitutional Court's and the Hungarian Supreme Court's - called Curia - jurisprudence. A clear trend may be identified from the regulation of referenda: the clearly "referendum-friendly" 1989 rules were amended to become mainly "parliament-friendly". It must be noted, that while the Hungarian constitutional system (unlike German or US system) still contains the institution of national referendum, the citizen-initiated "referendum threat" is decreasing tendentiously. Meanwhile, the political elite, especially the Government and the strongest parties have the greatest chance of organizing a successful referendum. The jurisprudence of the Constitutional Court and the Curia did not follow such a clear trend as the regulation. Both these bodies' jurisprudence contains decisions in favour of referenda and against this form of direct democracy, so their jurisprudence is in a constant flux.
\end{abstract}

\section{Keywords}

national referendum, Hungary, fundamental rights, Constitutional Court, interpretation of the constitution, direct democracy, representative democracy

1 Supported by the ÚNKP-17-4 New National Excellence Program of the Ministry of Human Capacities. 


\section{Introduction}

Finding the balance between the different forms of democracy is a key issue in all modern, democratic states. There is no general, ideal solution in the balance between representative and direct democracy that could easily be applied to all countries. In fact, this diversity in the role and forms of direct democracy may also be described and examined from a territorial and temporal perspective. The territorial perspective focuses on comparing states, while the temporal approach examines the changes of an issue over time in the very same country. This paper applies the temporal comparison: it gives an overview of the changes in the regulation of national referenda in Hungary since the change of political regime. Two constitutions $^{2}$, one relevant constitutional amendment, three acts on referenda and two acts on procedural issues, several decisions of the Constitutional Court (CC) and the supreme court - now called Curia - mark the three decades of referendum rules in the Third Hungarian Republic, that is, this period abounded with model changes.

The aim of this paper is to identify the trends and direction of Hungarian referenda-related legislation and their interpretation. The paper tries to determine the beneficiaries of the different models - for example the political elite (governmental or opposition parties), emerging political groups, or voters as non-professional (occasional) partakers of politics. For this purpose, the paper relies on the methodology of the science of constitutional law: primarily, the examination and interpretation of legal sources - constitutions, statutes and decisions. I examine the Hungarian regulation of national referenda by concentrating on its most important elements. Firstly, I focus on the basic regulation-model of national referenda asking the question: is the model state-centred or fundamental rights oriented? The state-centred interpretation of direct democracy leaves a broader margin of appreciation to the legislator in determining the limits of referenda, while it does not pay much attention to the availability of remedy forums. Meanwhile, the fundamental rights oriented approach is beneficial for individual voters, since they have better chances of enforcing their interests. Secondly, the form of regulation raises the problem of institutional guarantees: which state body is best placed to decide on referendum questions? This aspect sheds light on another face of referenda: the system of separation of powers. On the one hand, the referendum per se can be interpreted as an element of the system of separation of powers ${ }^{3}$. On the other hand, state bodies having competences in the referendum process can also shape the system of checks and balances via the application and interpretation of the relevant legal rules. Thirdly, I will focus on the changes of issues, which affect the role of national referenda: the personal scope of rules governing the submission of referendum initiatives (who?), issues on which holding a referendum is compulsory, admissible and excluded topics (about what?), result (is there a minimal turnout?), effect of the referendum (is the result of the referendum binding?). ${ }^{4}$

2 To distinguish the two constitutions, the paper uses the term "Constitution" to refer to the first codified constitution of Hungary, namely, Act XX of 1949, which was largely amended in 1989. The new constitution of Hungary was adopted by the Parliament in 2011, and its official designation is "Fundamental Law".

3 ACKERMAN, Bruce: The New Separation of Powers, in: Harvard Law Review, 113, 2000, 3, 667.

4 On the main points of referendum-regulation see also: KOMÁROMI, László: Közvetlen demokratikus hagyományok és modellek: alapkérdések, kockázatok és esélyek [Direct Democracy Traditions and Models: Funda- 


\section{State-centred and fundamental rights oriented models governing referenda}

\section{General remarks}

The dual nature of suffrage is commonly accepted in the field of constitutional law: it is first and foremost a means of establishing the representative bodies of the state - raising problems of legitimacy and sovereignty - but it also contributes in part to the creation of the system of state bodies. Meanwhile, suffrage also has a fundamental right aspect, it being a political participation right declared by constitutions. Although this Janus-faced nature of suffrage is well-known, dealing with its fundamental right aspects is exceptional both in the jurisprudence and the practice of courts or constitutional courts. ${ }^{5}$

Even less attention is paid in jurisprudence to the other important political participation right, the right to take part in a referendum. The dual nature of suffrage, as emphasized above, is also a relevant characteristic of the right to take part in a referendum. Referen$\mathrm{da}$ - and all other forms of direct democracy - are closely associated with the problem of legitimacy and sovereignty, so their constitutional role, the limits of these institutions are interpreted rarely in the frames of fundamental rights and in the context of fundamental rights' dogmatics. The lack of a fundamental rights oriented interpretation of referenda is further reinforced by constitutions, too. While suffrage belongs to the minimum-content of constitutions, the right to take part in a referendum can easily be left out of the list of fundamental rights - even in those countries, which recognize the institution of national referendum and have a codified constitution. ${ }^{6}$

\section{A fundamental right is born}

In the course of the nearly three decades history of the third Hungarian republic, the instrument of referendum played an important role in the political and constitutional system. For example, the first referendum was held just one month after the 'regime changing' constitutional amendment which came into effect on 23 October 1989. The so-called "fourtimes-yes referendum" 7 was initiated by four parties of the former opposition and thanks to its success the President of the republic was elected at the constitutive session of the parliament formed in April 1990. This led to the amendment of the procedure for the election of the head of state, a system originally conceived by the "national roundtable" 8 which

mental Questions, Risks and Opportunities], in: A népszavazás szabályozása és gyakorlata Európában és Magyarországon [Legal Framework and Practice of Referendums in Europe and Hungary], GÁVA, Krisztián - TÉGLÁSI, András (eds.), Budapest 2016, 144-146.

5 BODNÁR, Eszter: A választójog alapjogi tartalma és korlátai [The Substance and Limits of the Fundamental Right of Suffrage], Budapest 2014, 9.

6 CSINK, Lóránt: A Kúria határozata a Paksi Atomerőmű bővítésével kapcsolatos népszavazásról [The Decision of the Curia on the Referendum About the Enlargement of the Nuclear Power Station in Paks], in: Jogesetek Magyarázata [Explanation of Legal Cases], 5, 2014, 3, 40.

7 The commonly known name of this referendum derived from the number of the questions posed in this referendum and the initiating parties' suggestion for the outcome of the vote ("yes" instead of "no").

8 The National Roundtable was a special body involved in the change of regime, which included the state party 
has as its aim to prevent the appointment of a socialist politician. ${ }^{9}$ Hence, one of the crucial turning points of the change of political regime was decided by way of referendum, it had an influence on the form of government, the system of the separation of powers and finally, it prevented the Socialist Party from preserving its power.

While this form of direct democracy was of key significance, exercising referenda was not based on a fundamental right, since the 1989 text of the constitution did not set forth the right to take part in a referendum. It merely declared that the people shall exercise their power "through their elected representatives or directly". ${ }^{10}$ With a 1994 amendment of the constitution ${ }^{11}$ the right to take part in a referendum became a genuine fundamental right. ${ }^{12}$ Between 1989 and 1994 the right to take part in a referendum was provided for and regulated by the Act on referendum. ${ }^{13}$ The only constitutional basis for exercising direct democracy was the abovementioned general declaration in the constitution on the forms of democracy. But this also meant that there was no constitutional restriction on the concrete method(s) of exercising direct democratic power. The exercise of direct democratic power may take several forms: from the compulsory referendum through agenda initiatives $^{14}$ to the exercise of the freedom of assembly ${ }^{15}$. At the same time, the textual - and restrictive - interpretation of the constitutional provision would allow for the abolition of the referendum as long as one - necessarily weaker - form of direct democracy exists. ${ }^{16}$ Nevertheless, in 1991 the Constitutional Court opted for a different interpretation of Article 2 (2) of the Constitution, and declared that "the right to take part in a referendum is a fundamental right derived from the sovereignty of the people". ${ }^{17}$ Thus, the right to take part in a referendum was treated as a fundamental right in the period between 1991 and 1994, notwithstanding the fact that it was (merely) based on the CC's extensive interpretation of a principle enshrined in the Constitution. ${ }^{18}$

(Hungarian Socialist Party of Workers), the oppositional forces (which could not function as real political parties owing to the single party system) and the so-called "Third Side" (quite weightless next to the state party and the opposition). The role of the National Roundtable was to ensure the peaceful change of regime, to prevent a revolution. Decisions made by the National Roundtable were accepted by the parliament of the party state, so the Roundtable - and not the parliament - was the forum of real political negotiations and decision-making in questions which were crucial for the democratic transition.

9 The direct election of the head of state would have presumably resulted in the victory of a socialist politician, because just after the change of regime socialist politicians were well known by the people.

10 Act XX of 1949 on the Constitution of the Republic of Hungary Article 2 (2).

11 Act LXI of 1994 on the modification of Act XX of 1949 on the Constitution of the Republic of Hungary.

12 Article 70 (1) of the Constitution: "All adult Hungarian citizens residing in the territory of the Republic of Hungary have the right to be elected and the right to vote in Parliamentary elections, local government elections or minority self-government elections, provided that they are present in the country on the day of the election or referendum, and furthermore to participate in national or local referenda or popular initiatives."

13 Act XVII of 1989 Article 2 (1): "Voters have the right to take part in a referendum and people's initiative."

14 For the forms of direct democracy see: BERAMENDI, Virginia et al.: Direct Democracy. The International IDEA Handbook, Stockholm 2008.

15 Although it is quite strange to classify the freedom of assembly as a form of direct democracy, it is based on the decision no. 30/2015. (X. 15.) of the Constitutional Court, which stated that "the freedom of assembly shall be interpreted as a manifestation of direct democracy".

16 GYŐRFI, Tamás et al.: Alkotmányos alapelvek, ellenállási jog [Constitutional principles, right to resistance], in: Az Alkotmány kommentárja [Commentary of the Constitution], JAKAB, András (ed.), Budapest 2009, 227, footnote 355.

17 Decision no. 987/B/1990/3. of the CC.

18 At this point, it should be noted that the extensive interpretation of the constitution was a common phenom- 
Irrespective of the CC's 1991 decision, in 1994 the referendum received a more solid, codified constitutional basis, creating a new model of referendum: a fundamental right. Since the emergence of the institution of referendum raised a special aspect of the separation of powers by directly involving the people in legislation, the new model also impacted on the parliament's autonomy (increasing its constitutional elbow-room).

A constitutional amendment which came into effect in 1997 also affected the scope of the right to take part in a referendum. Namely, several detailed rules on the scope of this right were enshrined in the constitution, such as the requirements surrounding the initiation of a referendum (e. g. the subject-matter of the referendum must fall under the competence of the parliament, meanwhile, several subject-matters were also excluded from referendum at the time)..$^{19}$

Hungary's new constitution of 2011, the so-called Fundamental Law preserved the right to take part in a referendum as a fundamental right. It followed the 1997 regulatory model on the detailed regulation of direct democracy, albeit the list of excluded subject-matters was partly amended. ${ }^{20}$ However, it wasn't just the constitutional provisions that were renewed after 2010: new acts on referendum ${ }^{21}$ and the electoral procedure ${ }^{22}$ were adopted by the parliament.

\section{The structure of the right to take part in a referendum}

\section{Objective and subjective scope of the right}

The CC examined the structure of the right to take part in a referendum in its 1997 decision. It clarified, that this right covers both participation in voting in the referendum (the narrow substance of the right) and submitting the referendum initiative, supporting the initiative by signing it and, what is implied: the collection of signatures (broader substance of the right). The implicit limitations of the fundamental right model must be also noted: initiation cannot be interpreted as a fundamental right in case the initiator is a state body. This is important, because according to the Constitution and the Fundamental Law, voters, the Government and the President of the republic may submit a referendum initiative. Since 1997 the rules governing referenda are located in three chapters of the constitutional document - be it the Constitution or the Fundamental Law. ${ }^{23}$ The declaration of the existence

enon in the CC's jurisprudence, especially in the first era of its operation. The so-called "Sólyom Court" - which was named after the president of the CC - developed the concept of the "invisible constitution" in the 1990s. The invisible constitution was constructed from the decisions of the $\mathrm{CC}$, and its name reflected the concept that the real meaning of the constitution could not be gleaned merely from the constitution's text. Instead, it only became visible through the jurisprudence of the CC, with the CC stipulating for itself a great freedom in the interpretation of the constitution. Following the millennium and owing to personnel changes in the CC, the level of the court's activism was consolidated.

19 See point 5.1.

20 Article 8 of the Basic Law.

21 Act CCXXXVIII of 2013 on Initiating Referenda, the European Citizens' Initiative and Referendum Procedure.

22 Act XXXVI of 2013 on Electoral Procedure.

23 Since 1997 - when the right to take part in a referendum and the detailed regulation on referenda became part of the Constitution - the Constitution and the Fundamental Law regulated this aspect of the referendum in 
of direct democracy is enshrined in the chapter on principles. The detailed rules can be found in the chapter on state organization (following the rules on parliament), and the right to take part in a referendum is part of the chapter on fundamental rights. Although the possibility of submitting a question for referendum by voters, the Government and the head of state is foreseen in the same article of the constitution (in the chapter on state bodies), an initiative submitted by the Government or the head of state cannot be interpreted as exercising a fundamental right, since state bodies do not have fundamental rights. As such, the possibility of state bodies to submit referendum initiatives is a simple competence-rule, not a fundamental right provision. It strengthens the state-centred model of regulating referenda. The CC solved the discrepancy between the fundamental right oriented model of referendum and the competence of the Government and the president of the republic to initiate a referendum in a peculiar way: the $\mathrm{CC}$ declared, that the only real form of direct democracy is the referendum initiated by the voters. ${ }^{24}$

Focusing only on the right to take part in a referendum it must be noted, that the Constitution and the Fundamental Law declared it to be a right which can be exercised by "every adult Hungarian citizen". That is, the constitution-making power regulated this right as the right of those persons who have Hungarian citizenship. The CC enlarged the personal (subjective) scope of this right, by deeming it a collective right: collectives of voters (adult Hungarian citizens) - especially parties - can also exercise the right to take part in a referendum, because they play relevant role in the referendum process, in particular, in the collection of signatures. ${ }^{25}$

\section{Test for reviewing the restriction of the right to take part in a referendum}

The CC distinguished between the permissible levels of restricting the right to take part in a referendum depending on the status of the referendum process. In the majority of the cases (the initiation, the collection of signatures, supporting the referendum initiative by signing it, taking part in the voting) the right may be restricted according to the general test governing the restriction of fundamental rights. ${ }^{26}$ Such a restriction then affects the subjective aspect of this right, since individual rights are affected in these cases. However, there are several points in the process, where the objective aspects of the right will be stronger than the protection of individual rights. This aspect is particularly apparent at the point where the certification of the referendum question initiated takes place (namely, the checking of its admissibility), because at this point, the whole constitutional system is affected by the referendum process. The protection at this point is aligned with the constitutional function of the referendum. ${ }^{27}$ While the $\mathrm{CC}$ did not expressly emphasize this, in

the very same way.

24 Decision no. 52/1997. (X. 14.) of the CC.

25 Decision 31/2013. (X. 28.) of the CC. For a critical interpretation of this decision see: TÉGLÁSI, András: A népszavazáshoz való jog mint alapjog [Right to Take Part in Referenda as a Fundamental Right], in: Acta Humana, 2, 2014, 2, 91-103.

26 The test has been termed "necessity and proportionality" test.

27 See also: PETRÉTEl, József: Az országos népszavazásról [On the National Referendum], in: Kodifikáció [Codification], 2016, 2, 15. 
practice, this meant that at the time, the level of protection was lower than the strict general test for the restriction of fundamental rights.

\section{Models for protecting the right to take part in a referendum}

Just like the evolution of the right to take part in a referendum, the creation of the system for protecting the right was not a straightforward process, involving several changes to the protection models of the referendum process.

\section{The parliament-centred model}

In the first years of the Third Republic, the right to take part in a referendum was not supported by a real - judicial - protection mechanism. The first Act on referendum ${ }^{28}$ established a parliament-centred model of referendum procedure. The procedure officially kicked off with the delivery of at least 50,000 signatures to the parliament's speaker. The certification of the submission meant only the checking of the number of valid signatures. ${ }^{29}$ There was no preliminary control of the referendum-question to ascertain whether it meets the requirements set forth by the act (i.e. that it falls under the competence of the parliament, and does not pertain to any of the excluded subject matters). This had two important consequences: (1) at the time the signatures were collected it was not for certain, that the question put forward by the referendum initiative was even admissible; and (2) it was the parliament who was to decide on the admissibility of the question (whether it pertains to any excluded subject matter, etc.).

This raised a serious question: is the parliament as a political body the appropriate forum for deciding on the legal admissibility of the referendum question initiated? With other words: is this a political or a legal question? Can the parliament be the ultimate guardian of the right to take part in a referendum, a right that in fact challenges its autonomy?

From a textual perspective it is questionable whether the lack of judicial protection was unconstitutional or not. The right to take part in a referendum was a statutory right, since the 1989 Act on referendum contained it as the right of each voter. Although "ubi ius, ibi remedium" is a general principle in democracies ${ }^{30}$, the exact scope of the right to legal remedy was seriously restricted by the Hungarian Constitution, which stipulated: "In the Republic of Hungary everyone may seek legal remedy, in accordance with the provisions of the law, to judicial, administrative or other official decisions, which infringe on his rights or justified interests." ${ }^{31}$ Since the parliament is not a judicial, administrative body nor an

\footnotetext{
28 Act XVII of 1989.
}

29 The 1998 and 2013 Acts on referendum treat the certification of initiated questions and the verification of supporting signatures (i.e. the checking of the number of valid signatures) as different institutions.

30 See also Marbury v. Madison 5 U.S. 137 (1803): "The Government of the United States has been emphatically termed a government of laws, and not of men. It will certainly cease to deserve this high appellation if the laws furnish no remedy for the violation of a vested legal right. [...] [W] here a specific duty is assigned by law, and individual rights depend upon the performance of that duty, it seems equally clear that the individual who considers himself injured has a right to resort to the laws of his country for a remedy."

31 Act XX of 1949 Article 57 (5) In this context "official decision" means "decision made by an authority (part of the executive power)". 
authority, there was no express constitutional basis for creating a remedy against a parliamentary resolution ordering a referendum or rejecting it. Meanwhile the situation remained unchanged notwithstanding the 1991 decision of CC, who declared the right to take part in a referendum to be a fundamental one. In fact, even after the 1994 constitutional amendment that enshrined this right into the text of the Constitution the situation remained the same, since the right to legal remedy was not premised on the statutory or fundamental character of the right concerned. In conclusion it may be noted, that when it came to the right to take part in a referendum the text of the Constitution required a lower level of protection than what should have been guaranteed based on general democratic principles and common sense (namely, it could be the case that it is not in the interest of the parliament to order a referendum).

\section{The Constitutional Court-centred model}

In its decision no. 52/1997. (X. 14.) the CC set forth the constitutional requirement that the remedy of a constitutional complaint against decisions on referendum be established, for taking part in a referendum is a fundamental political right. The CC further declared that the preliminary control of the constitutionality of initiated referendum questions must be ensured.

The timing of the $\mathrm{CC}^{\prime}$ decision was quite peculiar: as outlined above, the right to take part in a referendum had been a fundamental right since 1991, that is, the CC waited six years before stipulating these constitutional requirements. Otherwise it was clear, that the lack of remedy against the parliament's resolution on the rejection of a national referendum was unconstitutional irrespective of whether the right concerned was a fundamental right or just a statutory right.

In 1997 the CC declared, that the protection of the objective side of the right to take part in a referendum must be reinforced by procedural guarantees, to ensure that referenda initiated can in fact be held with no political factors influencing the process, apart from the will of the voters. This requirement made the establishment of legal controls and remedies necessary at several points of the process. The CC stated that this control shall be ensured by the ordinary courts or by the CC itself. While the CC did not differentiate between the two types of legal control in the grounds of the decision, the operative part of the decision stipulated the mandatory involvement of the $\mathrm{CC}$ in the system of remedies against certification decisions. ${ }^{32}$

The Parliament fulfilled these constitutional requirements, establishing the National Election Committee ${ }^{33}$ as a body responsible for the preliminary ${ }^{34}$ certification of referendum questions submitted with the CC controlling the decisions rendered by the NEC. The ordinary remedy forum of NEC's decisions was the CC, which was empowered and obliged

32 Although this paper focuses primarily on the models established for the protection of the right to take part in a referendum, it must be mentioned that the $\mathrm{CC}$ extended its own scope of competences with this decision. Later, this competence of the CC acquired great significance, and with it, the CC actually strengthened its status in the system of separation of powers to the detriment of the parliament.

33 Hereinafter: NEC.

34 It was preliminary, because it preceded the collection of signatures. 
to control whether the NEC's decisions conformed to the requirements laid down in the Constitution and in the Act on referendum. In fact, this competence is an outlier among the ordinary competences of the CC, which are related only to constitutional issues.

The Parliament elaborated a detailed referendum process in 1998, with explicit regard to the right to remedy. Besides supervising the certification of referendum questions, the CC controlled the parliament's resolutions ordering or rejecting referenda. Ordinary courts namely the Supreme Court - were the remedy forum proceeding in cases where NEC decisions rendered on the authentication of the number of supporting signatures, the number of votes and issues relating to referendum campaigns were challenged. Although the ordinary courts also held remedy competences, the most important points of the process were controlled by the CC with the opportunity to influence NEC practice, developing hereby the conditions of direct democracy on the national level. Since the CC had the final say at the most crucial points of the referendum process, this system is called a Constitutional Court-centred model.

Of course, the CC-centred model also has its benefits and disadvantages. The most important argument speaking for this model is the strong constitution-centredness of the certification of referendum questions. The interpretation of the requirements governing the referendum question's certification (both as to whether it falls under the parliament's competence and is not an excluded subject-matter) and the relationship between direct and representative forms of democracy (fine-tuned by each decision rendered on the certification of a referendum question) go to the heart of constitutionalism, often resulting in "hard cases". From this point of view, the most competent forum for taking the final decision on the referendum question's certification is the CC. The difficulty of this task is well evidenced by the fact that in respect of the scope of parliamentary competence, the CC changed its jurisprudence twice within just two decades. ${ }^{35}$ But the interpretation of several excluded subject-matters - such as hidden amendments of the constitution or questions concerning fiscal issues - were also specified in the CC's practice, which must be interpreted in the light of other rules and principles of the constitution. Owing to its competence in referendum cases, the $\mathrm{CC}$ could develop a consistent practice on issues related to referenda and other cases, too.

The biggest disadvantage of this model was that it exacerbated the case-load of the CC. Especially in 2006 and 2007, when the number of the referenda initiated and remedy cases was extremely high, their topics often frivolous ${ }^{36}$, adjudicating these cases necessitated ample time, increasing the number of remainder $\operatorname{cases}^{37}$.

\section{The Curia-centred model}

In the framework of the general overhaul of Hungary's legal system between 2010 and 2014, the referendum procedure and the competences of the CC were also amended. The

\section{See point 4.}

36 For example: "Do you agree that the beer shall be free in restaurants and bars?" or "Do you agree that the president of the republic shall use a scooter instead of ministerial car?". Although these questions are obviously inappropriate for a referendum, the decision-making was nevertheless surprisingly complex.

37 In 2010 the CC was in four years' (!) delay. https://alkotmanybirosag.hu/uploads/2017/08/statisztika_ossz.pdf. 
first step of the referendum procedure remained almost unchanged: the NEC decides on the certification of the referendum questions initiated. The remedy forum against NEC's decision changed: the Curia - formerly named SC - became the general control body of the NEC.

The disadvantages of this model must be also mentioned. Firstly, as a formal aspect, the issue of case-load should be addressed: Curia judges have a much higher case-load, than the members of the CC owing to their other competences. Accordingly, the Curia can dedicate much less time to a referendum case than the CC. ${ }^{38}$ This is all the more problematic, if we take into account the difficulty of these cases. As mentioned above, several aspects of the certification of referendum questions require the interpretation of the constitution. Besides the lack of time, another problem may be raised in relation to the interpretation of the constitution: due to the Curia's new competence, the number of the constitution-interpreting body's members was doubled. Although the decisions of the $\mathrm{CC}$ are binding upon everyone, in practice, the Curia can cut itself adrift from the CC. The reason for this is quite simple: the real chance to relegate the Curia's decision to the CC is quite low. With 2012 the institution of constitutional complaint was extended and, following the German model, the so-called 'real constitutional' complaint was introduced by the Fundamental Law and the 2011 Act on the CC.

The point of the real constitutional complaint is to create a quasi remedy forum against the decisions of the ordinary courts, if they are based on an unconstitutional interpretation of the law. The real constitutional complaint is not an ordinary type of remedy ${ }^{39}$, and it is really difficult to submit an admissible complaint. The following requirements must be met for an admissible complaint:

a) it can be submitted by the person or organisation affected by the court decision;

b) the court decision is contrary to the Fundamental Law;

c) the court decision violates their rights laid down in the Fundamental Law, and

d) the possibilities for legal remedy have already been exhausted by the petitioner or no possibility for legal remedy is available to him or her;

e) the decision was made regarding the merits of the case or was another decision terminating the judicial proceedings;

f) the conflict with the Fundamental Law significantly affects the court decision, or the case raises constitutional law issues of fundamental importance.

Points e) and f) are classical 'de minimis'-rules giving a broad margin of discretion to the $\mathrm{CC}$ in deciding whether or not to accept a complaint. These conditions are the most important filters preventing the CC from turning into a part of the judiciary. The CC relies on these points often as the basis for refusing complaints ${ }^{40}$, but it has particularly stressed the significance aspect in referendum cases, because the $\mathrm{CC}$ only deals with those parts of the

38 RADICS, Katalin Adél: Ami a Parlamentet is köti: népszavazás a jogalkalmazók szemszögéből [By What Even the Parliament is Bound: Referendum from the Point of View of Those Applying the Law], in: Parlamenti Szemle [Parliamentary Review], 3, 2018, 1, 161.

39 In the exact words of the Hungarian law, the constitutional complaint is not a "remedy", it just has the characteristics of a remedy.

40 Decision no. 3195/2015. CC. 
Curia's decision that are directly based on the Fundamental Law. As pointed out above, there are several requirements that must be met for the certification of the referendum question; these are based on Act on referendum, not the constitution. The CC's decision will be without prejudice to the Curia's decision in these (non-constitutional) aspects, even if they influence the enforcement of the right to take part in a referendum. ${ }^{41}$

The condition laid down in point $d$ ) is automatically met, since the Curia is the highest forum in the system of the ordinary judiciary, therefore, legal remedy is not available against its decisions. The requirement under point $b$ ) is fulfilled in case the complaint meets the requirement set forth in point c): a decision that violates a fundamental right is per se contrary to the Fundamental Law (because it is the Fundamental Law that contains the fundamental rights).

In respect of point c), it is of course the right to take part in a referendum and the right to fair trial upon which the complaint may be based. Therefore, most of the decisions of the CC dealing with Curia decisions on the certification of referendum questions interpret the scope of the right to take part in a referendum. This element of the acceptance-test is particularly strict: there are hundreds of rules in a constitution that do not form part of the chapter on fundamental rights (fundamental principles, values, procedural rules, rules on competences, etc.). The CC interprets this requirement extremely narrowly: a complaint stated, that the Curia erred in its interpretation of the parliaments' competence (see the requirements applicable to the certification a referendum question), yet the $\mathrm{CC}$ did not consider this to be grounds for allowing the complaint. Hence, a general reference to the violation of the right to take part in a referendum owing to the misinterpretation of a certification requirement (even where this is contained in the Fundamental Law) shall not suffice for the CC to declare the violation of this right. ${ }^{42}$

Point a) is also a narrowly interpreted element of the acceptance-test, because the CC stated, that the mere fact that an individual has the right to vote shall not make him directly concerned by the Curia's decision. ${ }^{43}$

\section{Some issues affecting the status of referenda in the constitutional system}

\section{Subject-matters}

Subjects-matters play the most important role in increasing or limiting the relevance of referenda in a constitutional system: if there are topics where holding a referendum is compulsory, direct democracy has automatic avenues to prevail. On the other hand, the legal and political elbow-room of the bodies of representative democracy can be ensured by stipulating topics excluded from referendum subjects. The greater the number of compulsory subject-matters, the stronger direct democracy will be, meanwhile, increasing the number of excluded topics will weaken direct democracy.

41 Decision no. 28/2015. (IX. 24.) CC.

42 Decision no. 3003/2014. (I. 31.) CC.

43 Decision no. 3150/2016. CC. 
Although the 1989 Act on referendum expressly declared that a new constitution shall be reinforced by a national referendum, the $\mathrm{CC}$ excluded the people from partaking in the constitution-making power, as this is the exclusive competence of the parliament. ${ }^{44} \mathrm{Be}$ tween 1989 and 1993 no new constitution was made, hence, this compulsory referendum topic was never applied in practice.

There was only one topic where holding a referendum was compulsory according to the constitution, namely, EU-accession. Of course, it was not a normative rule of the Constitution, and after the holding this referendum in 2003, this rule was automatically repealed. Except for the unconstitutional requirement laid down in the 1989 Act on referendum and the "single use" rule on the compulsory referendum on EU-accession, the mandatory referendum was not part of the Hungarian constitutional system.

Since the change of political regime, the most important requirement regarding the subject matter of the referendum initiative is that it must fall under the competence of the Parliament. Because of the general legislative competence of the Parliament, at first sight this requirement is only a distinction between the subjects regarding national and local issues and accordingly, between national and local referenda ${ }^{45}$, but it can be used as a real restriction of national referendum initiatives. The role of this requirement must be interpreted in the light of the Parliament's legislative power. As mentioned above, the CC's jurisprudence changed twice in this subject-matter, but finally the CC chose the 'referendum-friendly' interpretation. On the other hand, the Curia interprets this requirement in a highly restrictive - and in my opinion unconstitutional - way. The concrete question was the following: if the Parliament authorized the Government or a member of the Government to regulate a topic, does the Parliament lose its legislative power this very area? Although acts adopted by the Parliament rank higher in the hierarchy of legal norms, than governmental decrees, the Curia declared that Parliament loses its legislative power in such cases. ${ }^{46}$ The Curia's interpretation favours the parliamentary majority and its politically loyal Government. This makes it easy to forego referendum initiatives on certain topics: the Parliament only needs to authorize the Government to regulate that topic, and the topic is thereby excluded from the competence of the Parliament and hence, from the subject-matters of referenda. ${ }^{47} \mathrm{It}$ was debated, whether the question underlying the "migrant quota referendum" falls under the competence of the Parliament, since it read as follows: "Do you want to allow the European Union to mandate the resettlement of non-Hungarian citizens to Hungary without the approval of the National Assembly?" The question had as its subject the competences of EU decision making bodies, not the Hungarian Parliament. Nevertheless, the Curia interpreted this requirement in a referendum-friendly way. ${ }^{48}$

44 Decision no. 2/1993. (I. 22.) of the CC.

45 Distinguishing between national and local questions is rarely a difficult task. This is well illustrated by the "NOLYMPICS" referendum initiative. Although the tender for the right to organize the 2024 Olympic Games seemed to have national relevance, formally it was Budapest as the capital city who was the candidate of the Olympic tender (not the whole country). Therefore, only a local referendum could be held on rejecting Hungary's - Budapest's - application.

46 Decision no. Knk.37.807/2012/2. of the Curia.

47 For the history and questions related to the Parliament's competence see: ERDÖS, Csaba: A rendeleti szabályozás esete az Országgyűlés hatáskörével - avagy az Országgyűlés hatáskörébe tartozás mint népszavazási szűrő értelmezésének változásai [Changes in the Interpretation of the Parliament's Competence as a Filter for Referendum Initiatives], in: Új Nemzeti Kiválóság Tanulmánykötet [Proceedings of the New National Excellence Program], Győr 2017, 168-179.

48 The CC rejected the constitutional complaint submitted against the Curia's decision, because it was not admissible. (See point 4.3.). Decision no. 3151/2016. (VII. 22.) of the CC. 
Legal provisions governing referenda traditionally abound with excluded subject-matters. Excluded topics are those on which holding a referendum is prohibited, notwithstanding the fact that they actually do fall under the competence of the Parliament. The 1997 constitutional amendment not only elevated the rules on excluded subject-matters to the level of the constitution, but also extended the scope, the number of excluded topics. The 1989 Act on referendum foresaw only three excluded subject-matters (fiscal questions, personnel decisions and issues relating to international treaties), while the 1997 constitutional amendment listed ten (!) excluded topics. The Parliament, as the legislator of the constitutional amendment, did not follow the CC's decision on declaring constitutional amendments to be an excluded topic, because the Constitution following its 1997 amendment merely declared its provisions on national referenda to be excluded subject-matters. In spite of the Constitution's text, the CC upheld its jurisprudence on this question, and it defended the entire text of the constitution from referendum initiatives.

The Fundamental Law changed the scope of excluded subject-matters, but it was much rather a fine-tuning than a model-change: it specified constitutional amendments in conformity with CC jurisprudence, extending the list of excluded topics with acts governing the election of MPs, MEPs, local self government representatives and mayors. The next table shows the changes made regarding the extent of excluded subject-matters:

Table 1 Overview of excluded subject matters

\begin{tabular}{|c|c|c|}
\hline 1989-1997 & 1997-2011 & 2012- \\
\hline- & $\begin{array}{l}\text { provisions of the Constitution on } \\
\text { national referenda }\end{array}$ & $\begin{array}{l}\text { any matter aimed at the amend- } \\
\text { ment of the Fundamental Law }\end{array}$ \\
\hline \multicolumn{3}{|c|}{$\begin{array}{l}\text { the contents of the Acts on the central budget, the implementation of the central budget, central taxes, } \\
\text { duties, contributions, customs duties or the central conditions for local taxes }\end{array}$} \\
\hline- & - & $\begin{array}{l}\text { the contents of the Acts on the } \\
\text { elections of Members of the Na- } \\
\text { tional Assembly, local govern- } \\
\text { ment representatives and may- } \\
\text { ors, or Members of the European } \\
\text { Parliament }\end{array}$ \\
\hline \multicolumn{3}{|c|}{ any obligation arising from international treaties } \\
\hline \multicolumn{3}{|c|}{$\begin{array}{l}\text { personnel matters and matters concerning the establishment of organizations falling within the competence } \\
\text { of the National Assembly (Government's program) }\end{array}$} \\
\hline- & \multicolumn{2}{|c|}{ the dissolution of the National Assembly } \\
\hline- & \multicolumn{2}{|c|}{ the dissolution of a representative body of a self-government } \\
\hline- & \multicolumn{2}{|c|}{$\begin{array}{l}\text { the declaration of a state of war, state of national crisis or state of emer- } \\
\text { gency, furthermore the declaration or extension of a state of pre- } \\
\text { ventive defence }\end{array}$} \\
\hline- & \multicolumn{2}{|c|}{ any matter related to participation in military operations } \\
\hline- & \multicolumn{2}{|c|}{ the granting of general pardons (amnesty) } \\
\hline
\end{tabular}


The interpretation of excluded subject-matters affects the relationship between direct and representative democracy. Although both the CC and the Curia stated the need for a narrow interpretation of this requirements, their jurisprudence are in flux, particularly on budgetary issues.

\section{Personal scope of rules governing the submitting of referendum initiatives}

The most important indicator of the popular or elite (government or opposition)-friendly models of referenda is the personal scope of rules governing the submitting of referendum initiatives. The 1989 Act on referendum, the Constitution after 1997 and the Fundamental Law also foresaw a competence for initiating referenda for the head of state and the Government, but they also knew the popular initiative. The 1989 and 1997 rules ensured the submitting of referenda as a collective right of MPs. From 1989 to 199750 MPs (approx. $13 \%$ of MPs) could initiate a facultative referendum, between 1997 and 2011 one-third of the MPs held this right. Since this right could be exercised by a qualified minority of MPs, it was a right of the parliamentary opposition. ${ }^{49}$ This oppositional right was quite weak, because - just like the head of state and governmental initiated referendum, the one initiated by the opposition was a facultative referendum. This means, that the Parliament (with relative majority) decided freely on whether or not to order the referendum (i.e. it was a political question). Initiating a facultative referendum cannot be a tool for obstruction, 50 therefore, the opposition could not force the parliamentary majority to comply by submitting the initiative.

Although the referenda initiated by the Head of state or the Government were also facultative, thanks to party- and faction-discipline, the Government - leaning to the governmental side of parliament (the parliamentary majority) - can easily achieve the ordering of a national referendum. From this point of view, the rules governing initiating and ordering referenda are government-friendly. But what is the reason for a government-initiated referendum, if the Government - thanks to its majority in the parliament - can rule the legislative activity of the Parliament without the need for any form of direct democracy? On the one hand, political communication, and need for setting the agenda of political discourse may be the explanation for the existence of government initiated referenda. ${ }^{51}$ Another reason could be the system of qualified majority legislation: in Hungary there are several topics, which may be regulated by cardinal acts, i.e. acts adopted by a two-thirds majority of the MPs present. If the Government wants to amend a cardinal act, but does not have a two-thirds majority in the Parliament, the Government can force the Parliament's hand via a valid and conclusive referendum, because the decision made in a referendum is binding upon the Parliament. ${ }^{52}$

49 For the oppositional rights see: SMUK, Péter: Ellenzéki jogok a parlamenti jogban [Rights of Opposition in Parliamentary Law], Budapest 2008.

50 SMUK, Péter: Rights of Opposition in Parliamentary Law, Győr 2007, online: http://www.sze.hu/ smuk/Doktorilskola/Fokozatszerzes/Smuk/Summary_Smuk.pdf.

51 The last Hungarian referendum - the so-called "migrants-quota referendum" - was initiated by the Government and it suited to governmental policy, which has an anti-migration focus since 2015.

52 For this problem see point 4.4 . 
A voters-initiated referendum can be compulsory or facultative, depending on the number of signatures collected. In 1997 the number of signatures necessary was doubled, which made initiating a referendum much more difficult. It was a "parliament-friendly", and, accordingly "counter-referendum" amendment. It may be understood as a step, which confines the "civilian face" of referenda and emphasizes the role of the political elite in the referendum procedure - especially parties from the side of both the government and the opposition. Since 1997 the strongest form of direct democracy, the compulsory national referendum can only be initiated by 200,000 voters, representing approximately $2.5 \%$ of the voters. Although it is an not a strict requirement in international comparison ${ }^{53}$, collecting 200,000 valid signatures is almost impossible without the help of a party. ${ }^{54}$ Meanwhile, this threshold it is not a strong limitation for a well-organized party ${ }^{55}$.

The following table shows the changes affecting the initiation of compulsory and facultative referenda:

\section{Table 2 Changing of the minimum number of signatures needed for initiating a referendum}

\begin{tabular}{|c|c|c|c|c|c|}
\hline & 1989-1997 & \multicolumn{2}{|c|}{ 1997-2011 } & \multicolumn{2}{|r|}{ 2012- } \\
\hline Compulsory & 100,000 voters & - & 200,000 voters & - & 200,000 voters \\
\hline Facultative & $\begin{array}{l}50,000 \text { voters } \\
\text { head of state } \\
\text { Government } \\
50 \mathrm{MPs}\end{array}$ & $\begin{array}{l}- \\
- \\
-\end{array}$ & $\begin{array}{l}100,000 \text { voters } \\
\text { head of state } \\
\text { Government } \\
\text { one-third of MPs }\end{array}$ & $\begin{array}{l}- \\
- \\
-\end{array}$ & $\begin{array}{l}100,000 \text { voters } \\
\text { head of state } \\
\text { Government }\end{array}$ \\
\hline
\end{tabular}

Source: own compilation

Finally, another restriction of administrative nature to voter-initiated referenda should be noted: where the organiser of a citizen-initiated referendum is a private individual, the question shall be submitted with supporting signatures of at least twenty voters whose maximum number must not exceed thirty. This rule, which aims to prevent frivolous initiatives, was put into effect by the 2013 Act on referendum.

53 BERAMENDI et al., 69; KOMÁROMI, 153.

54 In the past decade there was only one initiative, that could collect more than 200,000 signatures without party support: in 2009 a private individual, Mária Seres initiated a referendum on the topic of the MP's allowance. Later she established a political party, this however did not become a relevant power in the Hungarian political system. In 2017 a local referendum initiative, the "NOLYMPICS" initiative was how the Momentum Movement entered the national political arena. Momentum become a party a few months after its referendum campaign, and it gained more than $1 \%$ in the 2018 parliamentary elections. It must be noted, that these two initiatives did not result in the holding of referenda, because the Parliament modified the regulation on MP's allowances and the representative body of the Budapest self-government withdrew its application for the 2024 Olympic games, following the collection of the necessary signatures, albeit just before the day of voting.

55 The incumbent governing party, Fidesz initiated a referendum on three questions in 2007. In that year Fidesz was an opposition party. The three questions were about social issues, which were in the focus of the Government's reforms, but they were extremely unpopular (university tuition fee, doctor's visit fee, fee for hospital stay). Fidesz collected more than 300,000 signatures within 48 hours(!). The Act on referendum ensured 120 days for collection. 


\section{Result}

Requirements set forth in respect of the referendum's result attest to the level of difficulty of achieving a legally binding result by referendum. The stringency of the relevant rules is evidenced by the legal distinction made between validity and conclusiveness. Validity means a turnout quorum, while conclusiveness refers to the distribution of valid votes. The stricter the turnout threshold, the less "referendum-friendly" the regulation is, because mobilization of voters is a difficult task.

During the three decades examined in this paper, two models of referendum results existed: between 1989 and 1997, and after 2012 distinction was made between validity and conclusiveness. In these periods, validity meant that more than half of all voters had cast valid votes (turnout). The referendum was considered as conclusive if more than half of those who had voted validly gave the same answer to the referendum question. In practice, this meant that a valid referendum could be non-conclusive, if each options of answer gains the same amount of votes. Since it is only a hypothetical possibility, it is clear, that it is validity, which is the relevant requirement.

The other model regarding referendum results was introduced only a few days prior to the referendum on NATO-accession. Surveys showed, that the expected turnout will not reach the $50 \%$ limit. An amendment of the constitution the formally abolished the turnout quorum, yet in the framework of the requirement of conclusiveness it was retained as an approval quorum ${ }^{56}$ : the votes cast in favour of a proposal must reflect $25 \%$ of registered voters. Hence, there was no explicit turnout quota, but a referendum would not be considered conclusive, if less than $25 \%$ of voters cast a valid vote. ${ }^{57}$

\section{Effects of referenda - Legal consequences}

The effect of a referendum may be binding or consultative. Before the Fundamental Law came into effect, the Hungarian rules governing direct democracy provided for a consultative type of national referendum. Despite the fact that the law foresaw a possibility of organizing a consultative referendum, no such referendum was held during this period. From this point of view, the Fundamental Law did not change the relationship between the direct and representative democracy de facto, but merely adjusted the rules to actual practice (reality).

The result of a referendum was never considered to be a source of law, so it was never directly applicable. The Parliament is the only addressee of the result of a valid and conclusive referendum. In light of the voters' decision, the Parliament shall adopt a new act, or amend, repeal or leave intact existing regulation. The result of a referendum shall bind the Parliament for a period of three years: during this period, law must meet with the ref-

\section{BERAMENDI et al., 69.}

57 The national turnout was $49.24 \%$ at the NATO referendum, so without the modification of the result requirements, this referendum would have been invalid (source: http://www.valasztas.hu/nep97/index.htm). The turnout at the referendum on EU-accession was $45.62 \%$, so it would have also been an invalid referendum according to the old/new regulation. The 2016 referendum on the migrant quota would have been conclusive, if the Fundamental Law would not have reintroduced the validity requirement (the turnout was $44.08 \%$ ). 
erendum's result. This is the strongest effect of the referendum when compared with other forms of direct democracy. There are several institutions, procedures which may be used to put political pressure on the Parliament (for example, by exercising the freedom of assembly), but the referendum is the only one which can restrict the Parliament's political and legislative elbow-room for a certain period of time. ${ }^{58}$

At the same time, the need for the Parliament to take action to implement the result of the referendum reflects the limitations of this form of direct democracy. The legally binding force of the referendum decision becomes illusory, if it cannot be enforced de facto. The Parliament as a whole (as a constitutional body) is obliged 'execute' the decision taken in referendum. But the single MPs have a free mandate, they shall not be called to account for their vote. If the Parliament neglects its legislative duty arising from a referendum decision, the only legal consequence can be the CC's decision establishing the Parliament's omission. Nevertheless, the rules stipulated by the referendum's results cannot be enacted without the Parliament.

\section{Conclusion}

During three decades of the Third Hungarian Republic, the national referendum's constitutional role and model changed several times owing to the amendment of the relevant legislation and the changes in the CC's and Curia's jurisprudence. As a conclusion, it can be stated that a clear trend may be identified from the regulation of referenda: the clearly "referendum-friendly" 1989 rules were amended to become mainly "parliament-friendly". It must be noted, that while the Hungarian constitutional system (unlike German or US system) still contains the institution of national referendum, the citizen-initiated "referendum threat" 59 is decreasing tendentiously. Meanwhile, the political elite, especially the Government and the strongest parties have the greatest chance of organizing a successful referendum. Restrictions have increasingly been put in place at crucial points of the regulation: the abolition of the compulsory referendum in the constitution-making process, increasing the number of the excluded subject-matters, doubling the number of the signatures needed for a citizens-initiated referendum reflect this course.

58 This is why the legality of not ordering a compulsory referendum is questionable, though the Act on CC foresees such an opportunity: the "CC shall only carry out an examination regarding the merits of the resolution if, between the authentication of the signature-collecting sheets and the ordering of the referendum, the circumstances changed to a significant degree in a manner that may significantly affect the decision, and if said changes could not be taken into account by the National Election Committee or the Curia when making a decision on the authentication of the question or the decision on the review thereof." Act CLI of 2011 on CC, Section 33.

It is typical in respect of "hot topics", that Parliament acknowledges the success achieved in collecting the necessary signatures, and thus modifies the regulation underlying the referendum initiated, in the way that conforms to the presumed will of the people. Such backing down can prevent a referendum which may easily be interpreted as a vote against the Government. (Such successful initiatives covered for example: MP's allowance, compulsory closing on Sundays in the retail sector, NOLYMPICS.)

59 The "referendum threat" can force professional politicians (the political elite) to consider the voters' will. This is an indirect effect of referenda, because it affects political conditions only through a mere possibility of a popular referendum. BÜCHI, Rolf: Reflections on the Social Production of Incompetent Citizens, in: Direct Democracy in Europe, PÁLLINGER, Zoltán Tibor - KAUFMANN, Bruno - MARXER, Wilfried - SCHILLER, Theo (eds.), Wiesbaden $2007,76$. 
There were some points in the regulation, which aimed at the strengthening of the citizen-initiated referendum. The most important element of this trend was the establishment of the fundamental rights-oriented model of direct democracy and the creation of a remedy system in the referendum process. As I have pointed out, it is difficult to interpret several aspects of referendum in the fundamental rights oriented model of the direct democracy, so it could not counterbalance those elements of the regulation which pose limitations to the citizen-initiated referenda. The changes in the models of protection for the fundamental right to take part in a referendum had institutional consequences, too. In fact, the interpretation and protection of this right led to the modification of the system of the division of powers. Bodies involved in the application of the relevant rules, and in particular, the CC had a great impact on the development of the regulatory framework. Indeed, the jurisprudence of the $\mathrm{CC}$ was decisive for the most recent change of protection model: without the strict interpretation of the acceptance test elements for the admissibility of constitutional complaints, access to the CC would be easier, and, as a result, the Curia would not have a leading role in the interpretation of the constitutional rules regarding the certification of referendum questions.

The role of those bodies which apply the rules governing referenda, namely the Curia and the $\mathrm{CC}$ is decisive for determining the place of the referendum in the constitutional system. The jurisprudence of these bodies did not follow such a clear trend as the regulation. The CC played a relevant role in the development of the regulation, sometimes even directly, by formulating constitutional requirements to be implemented by the legislator. Both the CC's and the Curia's jurisprudence contain decisions in favour of referenda and against this form of direct democracy, so their jurisprudence is in a constant flux. For example, the development of the fundamental rights oriented model of referendum was important for supporting and protecting direct democracy, and in particular, its strongest form, the citizen-initiated referendum. On the other hand, the enhanced protection of the Parliament's constitution-making power weakened direct democracy.

There are several break-out points in the Hungarian regulation of referenda. It is worth considering a conceptual turn in the relevant regulation: the present model focuses on the restriction of direct democracy; this is clearly shown by the number of excluded subject-matters. There are several examples from other countries, that the subject matters presently excluded in Hungary, are less threatening than they seem. Even if it is the political and constitutional culture that is decisive in the extension of direct democracy, introducing a compulsory referendum to approve constitution-making or amending legislation is recommended to ensure greater legitimacy for the Parliament's constitutional decision.

\section{References}

ACKERMAN, Bruce: The New Separation of Powers, in: Harvard Law Review, 113, 2000, 3, 633-729.

BERAMENDI, Virginia et al.: Direct Democracy. The International IDEA Handbook, Stockholm 2008.

BODNÁR, Eszter: A választójog alapjogi tartalma és korlátai [The Substance and Limits of the Fundamental Right of Suffrage], Budapest 2014. 
BÜCHI, Rolf: Reflections on the Social Production of Incompetent Citizens, in: Direct Democracy in Europe, PÁLLINGER, Zoltán Tibor - KAUFMANN, Bruno - MARXER, Wilfried - SCHILLER, Theo (eds.), Wiesbaden 2007, 71-81.

CSINK, Lóránt: A Kúria határozata a Paksi Atomerőmű bővítésével kapcsolatos népszavazásról [The Decision of the Curia on the Referendum About the Enlargement of the Nuclear Power Station in Paks], in: Jogesetek Magyarázata [Explanation of Legal Cases], 5, 2014, 3, 37-42.

ERDŐS, Csaba: A rendeleti szabályozás esete az Országgyűlés hatáskörével - avagy az Országgyűlés hatáskörébe tartozás mint népszavazási szűrő értelmezésének változásai [Changes in the Interpretation of the Parliament's Competence as a Filter for Referendum Initiatives], in: Új Nemzeti Kiválóság Tanulmánykötet [Proceedings of the New National Excellence Program], Győr 2017, 168-179.

GYŐRFI, Tamás et al.: Alkotmányos alapelvek, ellenállási jog [Constitutional principles, right to resistance], in: Az Alkotmány kommentárja [Commentary of the Constitution], JAKAB, András (ed.), Budapest 2009, 127-238.

KOMÁROMI, László: Közvetlen demokratikus hagyományok és modellek: alapkérdések, kockázatok és esélyek [Direct Democracy Traditions and Models: Fundamental Questions, Risks and Opportunities], in: A népszavazás szabályozása és gyakorlata Európában és Magyarországon [Legal Framework and Practice of Referendums in Europe and Hungary], GÁVA, Krisztián - TÉGLÁSI, András (eds.), Budapest 2016, 144-146.

PETRÉTEI, József: Az országos népszavazásról [On the National Referendum], in: Kodifikáció [Codification], 2016, 2, 5-42.

RADICS, Katalin Adél: Ami a Parlamentet is köti: népszavazás a jogalkalmazók szemszögéből [By What Even the Parliament is Bound: Referendum from the Point of View of Those Applying the Law], in: Parlamenti Szemle [Parliamentary Review], 3, 2018, 1, 157-161.

SMUK, Péter: Rights of Opposition in Parliamentary Law, Győr 2007, online: http://www. sze.hu/ smuk/Doktorilskola/Fokozatszerzes/Smuk/Summary_Smuk.pdf.

SMUK, Péter: Ellenzéki jogok a parlamenti jogban [Rights of Opposition in Parliamentary Law], Budapest 2008.

TÉGLÁSI, András: A népszavazáshoz való jog mint alapjog [Right to Take Part in Referenda as a Fundamental Right], in: Acta Humana, 2, 2014, 2, 91-103.

\section{Author}

Csaba Erdős JD, PhD.

Alkotmányjogi és Politikatudományi Tanszék, Deák Ferenc Állam- és Jogtudományi Kar, Széchenyi István Egyetem

Department of Constitutional Law and Political Sciences, Deák Ferenc Faculty of Law and Political Sciences, Széchenyi István University

Áldozat u. 12, 9026 Győr, Hungary

dr.erdos.csaba@gmail.com 